\title{
Patient blood management in Europe
}

\author{
A. Shander ${ }^{1 *}$, H. Van Aken ${ }^{2}$, M. J. Colomina ${ }^{3}$, H. Gombotz ${ }^{4}$, A. Hofmann ${ }^{5}$, R. Krauspe ${ }^{6}$, S. Lasocki ${ }^{7}$, \\ T. Richards ${ }^{8}$, R. Slappendel ${ }^{9}$ and D. R. Spahn ${ }^{10}$ \\ ${ }^{1}$ Department of Anaesthesiology, Critical Care Medicine, Pain Management and Hyperbaric Medicine, Englewood Hospital and Medical \\ Center, 350 Engle Street, Englewood, NJ, USA \\ ${ }^{2}$ Department of Anaesthesiology and Intensive Care, University Hospital, Münster, Germany \\ ${ }^{3}$ Department of Anaesthesia, Hospital Universitario Vall D'Hebron, Barcelona, Spain \\ ${ }^{4}$ Department of Anaesthesiology and Intensive Care, General Hospital, Linz, Austria \\ ${ }^{5}$ Centre for Population Health Research, Curtin Health Innovation Research Institute, Curtin University, Perth, Western Australia, Australia \\ ${ }^{6}$ Department of Orthopaedics, University Hospital Düsseldorf, Heinrich-Heine-University Düsseldorf, Düsseldorf, Germany \\ ${ }^{7}$ Division of Anaesthesiology and Reanimation, University Hospital Angers, France \\ ${ }^{8}$ Division of Surgery and Interventional Science, University College London Hospital, London, UK \\ ${ }^{9}$ Department of Quality and Safety, Amphia Hospital, Breda, The Netherlands \\ ${ }^{10}$ Institute of Anaesthesiology, University Hospital and University of Zurich, Zurich, Switzerland \\ * Corresponding author. E-mail: aryeh.shander@ehmc.com
}

\section{Editor's key points}

- Perioperative anaemia is common in patients presenting for major surgery.

- Blood transfusion has traditionally been the treatment, but this has a number of problems.

- Patient blood management aims to minimize the need for transfusion.

- Early detection and treatment of anaemia and minimizing blood loss are key strategies.
Summary. Preoperative anaemia is common in patients undergoing orthopaedic and other major surgery. Anaemia is associated with increased risks of postoperative mortality and morbidity, infectious complications, prolonged hospitalization, and a greater likelihood of allogeneic red blood cell (RBC) transfusion. Evidence of the clinical and economic disadvantages of RBC transfusion in treating perioperative anaemia has prompted recommendations for its restriction and a growing interest in approaches that rely on patients' own (rather than donor) blood. These approaches are collectively termed 'patient blood management' (PBM). PBM involves the use of multidisciplinary, multimodal, individualized strategies to minimize RBC transfusion with the ultimate goal of improving patient outcomes. PBM relies on approaches (pillars) that detect and treat perioperative anaemia and reduce surgical blood loss and perioperative coagulopathy to harness and optimize physiological tolerance of anaemia. After the recent resolution 63.12 of the World Health Assembly, the implementation of PBM is encouraged in all WHO member states. This new standard of care is now established in some centres in the USA and Austria, in Western Australia, and nationally in the Netherlands. However, there is a pressing need for European healthcare providers to integrate PBM strategies into routine care for patients undergoing orthopaedic and other types of surgery in order to reduce the use of unnecessary transfusions and improve the quality of care. After reviewing current PBM practices in Europe, this article offers recommendations supporting its wider implementation, focusing on anaemia management, the first of the three pillars of PBM.

Keywords: anaemia; outcome; patient blood management; transfusion
Anaemia affects $\sim 1.6$ billion people, $25 \%$ of the world's population. ${ }^{1}$ Iron deficiency is the principal cause of anaemia ${ }^{1}$ and is a major contributory factor to the global disease burden. ${ }^{2}$ Anaemia, which can be due to underlying conditions or surgical blood loss, is commonly found in patients undergoing surgery. ${ }^{3}$ Major orthopaedic surgery is associated with substantial blood loss, leading to a significant decrease in haemoglobin $(\mathrm{Hb})$ levels during surgery. ${ }^{4}$ A recent meta-analysis of 19 studies showed that $24 \%$ of patients undergoing total hip replacement (THR) or total knee replacement (TKR) and $44 \%$ of those with hip fracture had preoperative anaemia. As these procedures are associated with considerable blood loss (mean $1500 \mathrm{ml}$ ), ${ }^{6} 7$ after operation, $51 \%$ of patients undergoing THR/TKR and $87 \%$ of patients with hip fracture were anaemic. ${ }^{5}$ Between $22 \%$ and $75 \%$ of patients undergoing colorectal surgery and $34 \%$ of those undergoing other forms of non-cardiac surgery have also been reported to have preoperative anaemia. ${ }^{3}$ In a recent multicentre cohort study, the prevalence of preoperative anaemia in cardiac surgery patients ranged from $22 \%$ to $30 \%$. $^{8}$ Preoperative anaemia in patients undergoing major surgery is often caused by chronic disease, but hypochromic/ microcytic anaemia may require iron studies. ${ }^{9} 10$

Prospective and retrospective cohort studies have consistently shown that patients with preoperative anaemia have poorer postoperative outcomes than non-anaemic patients. Early data suggested that severe preoperative anaemia

(c) The Author [2012]. Published by Oxford University Press on behalf of the British Journal of Anaesthesia. All rights reserved. For Permissions, please email: journals.permissions@oup.com

This is an Open Access article distributed under the terms of the Creative Commons Attribution Non-Commercial License (http:// creativecommons.org/licenses/by-nc/2.5/uk/) which permits unrestricted non-commercial use, distribution, and reproduction in any medium, provided the original work is properly cited. 
$\left(\mathrm{Hb}<8 \mathrm{~g} \mathrm{dl}^{-1}\right)$ independently predicted postoperative mortality in patients undergoing various unspecified types of surgery. ${ }^{11} 12$ A recent retrospective cohort study demonstrated a higher postoperative 30 day morbidity and mortality in patients who underwent major non-cardiac surgery with preoperative anaemia than in those without anaemia. ${ }^{13}$ In elderly patients with hip fracture, anaemia ( $\mathrm{Hb}<12 \mathrm{~g} \mathrm{dl}^{-1}$ for females and $<13 \mathrm{~g} \mathrm{dl}^{-1}$ for males) was significantly associated with 2 - to 5 - and 3 -fold increases in the multivariate-adjusted risk of 6 and 12 month mortality, respectively. ${ }^{14}$ Patients with $\mathrm{Hb}<10 \mathrm{~g} \mathrm{dl}^{-1}$ were at a 5 -fold increased risk of death. Subsequent studies have confirmed the association between preoperative anaemia and postoperative mortality in this population, ${ }^{15}{ }^{16}$ and in patients undergoing other types of surgery. ${ }^{3} 1718$ In addition to mortality, preoperative anaemia is also significantly and independently associated with increased morbidity, including the elevated risk of infectious complications and a prolongation of postoperative hospital stay. ${ }^{14-16} 19$ Some studies have linked perioperative anaemia to impaired postoperative functional recovery after surgery for hip fracture, ${ }^{15} 1620$ although it was not an independent factor in a prospective multivariate analysis. ${ }^{16}$ In addition, anaemia is a risk factor for both early and late mortality in patients undergoing coronary artery bypass grafting (CABG). ${ }^{21}$

Transfusion may be regarded as the default therapy for anaemia, as it is considered as safe and is rapidly effective. However, accumulating, there is increasing evidence that the correction of preoperative anaemia using transfusion is associated with risks that may contribute to morbidity and mortality in surgical patients. ${ }^{22} 23$ Consequently, there is increasing recognition of new approaches to the management of anaemia, collectively referred to as patient blood management (PBM). 5222425 This article, based on discussions held by a panel of expert anaesthetists, surgeons, and nurses, explores the risks associated with the use of red blood cell (RBC) transfusions in the management of perioperative anaemia, primarily in orthopaedic surgery, and the role of PBM in improving the quality of care in this setting. It also highlights examples of successful PBM programmes, overviews current practice patterns in Europe, and offers recommendations for supporting the wider implementation of PBM.

\section{Transfusion and preoperative anaemia}

The Orthopaedic Surgery Transfusion Haemoglobin European Overview (OSTHEO) study prospectively analysed blood management data from 3996 patients undergoing elective orthopaedic surgery in Europe in $1999 .{ }^{26}$ Data were collected from 225 centres in France, Germany, Greece, Italy, the Netherlands, and Spain. Overall, 69\% of patients received transfusion, including $35 \%$ who received autologous transfusions only and $25 \%$ who received allogeneic blood transfusions (ABTs) only.

Around $45 \%$ of major orthopaedic surgery patients receive perioperative RBC transfusion..$^{5}$ Orthopaedic surgery is the leading surgical indication for transfusion, accounting for $\sim 10 \%$ of all RBC units transfused. ${ }^{27} 28$ Patients with preoperative anaemia are more likely to receive perioperative blood transfusions in the setting of orthopaedic,, 9101419262930 and other types of surgery, ${ }^{17} 30$ than non-anaemic patients. For example, in 1142 patients undergoing elective hip or knee surgery in the UK in $2000-1,42.0 \%$ of anaemic patients received a transfusion compared with $21.3 \%$ of patients overall, and a preoperative $\mathrm{Hb}$ level of $<11.0 \mathrm{~g} \mathrm{dl}^{-1}$ was strongly and independently associated with transfusion (odds ratio 13.92; $P<0.001) .{ }^{10}$ In a prospective, observational Austrian study, the main predictors for allogeneic RBC transfusions were preoperative and lowest $\mathrm{Hb}$ and surgical blood loss. ${ }^{30}$

The use of ABTs to correct anaemia in surgical patients is not supported by evidence of benefit. Transfusions increase $\mathrm{Hb}$ levels in critically ill patients, but they do not appear to reliably improve tissue oxygenation. ${ }^{31}{ }^{32}$ ABTs are associated with a number of risk factors that can be divided into transfusion-transmitted infectious complications (e.g. HIV and hepatitis), immunological complications [e.g. immunomodulation resulting in postoperative infection, sepsis, antibody-mediated alloimmunization, graft-vs-host disease (GVHD), haemolytic transfusion reactions, and allergic reactions], transfusion-related acute lung injury (TRALI; which has both immunological and non-immunological properties), and non-infectious non-immunological complications (e.g. acute lung injury, transfusion errors, non-haemolytic and haemolytic reactions, circulatory overload, and metabolic disturbances). ${ }^{22} 23$

Cohort studies have documented an increased risk of infectious complications, fluid overload, delay in wound healing, and prolonged hospital stay in transfused patients undergoing orthopaedic surgery. ${ }^{29}{ }^{33-36}$ Adverse transfusion outcomes have also been documented in critically ill patients, trauma patients, and cardiac or colorectal surgery. ${ }^{37}$

Observational studies have found higher postoperative mortality rates in transfused patients undergoing cardiac surgery compared with those who were not transfused, even after adjustment for other risk factors. ${ }^{38}$ Randomized controlled trials (RCTs) in patients undergoing cardiac surgery have shown that white blood cell (WBC)-reduced blood products carry a lower mortality risk than non-WBC-reduced products. ${ }^{23}$ However, this has not been observed after other types of surgery, and this issue is not resolved. ${ }^{23}$

TRALI, acute transfusion reactions, haemolytic transfusion reactions, transfusion-transmitted infections, circulatory overload, and (in the UK) transfusion-associated GVHD are the main causes of death and morbidity related to ABT. ${ }^{39} 40$ TRALI has a presentation similar to acute respiratory distress syndrome, which has also been linked to transfusion. ${ }^{41}$ Different models have been proposed for the pathogenesis of TRALI. ${ }^{42} 43$ An antibody-mediated immune reaction, whereby antibodies in donated plasma activate recipient neutrophils within the lung, has been proposed. ${ }^{43}$ Alternatively, the 'two-event' model proposes that factors present in transfused stored blood products trigger TRALI in patients in whom endothelial activation is already present due to an initial proinflammatory event, for example, infection, surgery, 
or trauma. ${ }^{42}$ Transfusion-related immunomodulation proposes that deleterious proinflammatory effects result from a complex interplay between transfusion effects, genetic factors, intercurrent illnesses, and inflammatory mediators and effector cells. ${ }^{44}$

However, a causal relationship between transfusion and these serious complications is not established. Much of the evidence for these complications comes from retrospective, uncontrolled, non-randomized, observational cohort studies that may be subject to bias and confounding factors, and predominantly demonstrate correlations rather than causal relationships. Patients who are less well relative to healthy patients are more likely to receive transfusion. Thus, transfusion may be a surrogate for other causes of poor outcome. However, the association between allogeneic RBC transfusions and adverse outcome has been shown so consistently over the last three decades, that causation is highly likely. ${ }^{45} 46$

The storage of donated RBCs has enabled a more efficient use of blood supplies. However, allogeneic blood undergoes changes during prolonged storage (storage lesions), which may affect patient outcome. These changes include the accumulation of proinflammatory metabolic and breakdown products (e.g. lysophospholipids) that may be linked to TRALI, changes in cell shape, acidosis, membrane loss, haemolysis, increased rigidity, and stronger endothelial attachment. ${ }^{44} 47$ Some studies have correlated the use of older, stored RBCs with an increased risk of complications and mortality in cardiac surgery and trauma patients. ${ }^{48} 49$ However, the impact of storage on post-surgical outcome is a matter of debate. ${ }^{44}$ The evidence supporting this association comes from observational studies that could be subject to bias and confounding factors. Some studies have reported that the storage age of RBCs was not independently associated with poorer outcomes, ${ }^{50}$ while a recent meta-analysis concluded that the available data do not support an association between older RBCs and increased morbidity or mortality. ${ }^{51}$

The risks of transfusion are acknowledged by the American Association of Blood Banks, American Blood Commission, and American Red Cross. ${ }^{52}$ The 2009 International Consensus Conference on Transfusion and Outcomes (ICCTO; Phoenix, AZ, USA) concluded that, based on available evidence and considering a number of scenarios in which transfusions are commonly given, $A B T$ is not likely to improve patient outcome in most scenarios (but may even cause harm). The impact of ABT on patient outcomes remains uncertain and in need of further investigation, providing a rationale for more judicious use of ABT. ${ }^{53} 54$

Additional disadvantages with the use of transfusions relate to scarcity and cost of blood. The supply of blood for transfusions is limited by an ageing population and increasingly restrictive screening criteria. The chain of supply can also be overwhelmed by disaster events, potentially leading to blood shortages at the local level. While more blood may be donated in response to disaster events, the daily supply margin is limited and days during which there is a sudden increase in the use can disrupt the blood supply. While this may be a problem in developing nations, it may still affect first-world countries with established infrastructure. $^{22}$ The increasing scarcity of blood and measures to reduce the risks of infection transmission have increased the direct costs of transfusion. ${ }^{55}$ The true costs of transfusion services are likely to have been underestimated owing to their complexity. A detailed study of the costs associated with all activities involved in providing transfusion services in surgical patients in four hospitals in the USA, Austria, and Switzerland recently estimated expenditures ranging from $\$ 1.62$ to $\$ 6.03$ million per hospital. The total costs were 3- to 5-fold higher than blood product acquisition costs alone. ${ }^{56}$ Indirect costs have previously associated with the legal ramifications of contaminated blood supplies, and also the personal costs to affected donors and patients. $^{56-58}$

Despite the risks, limited benefits, costs, and scarcity, a substantial proportion of RBC transfusions given today may not be appropriate or justified according to the report of the ICСТО panel and several reports on variable transfusion practices in otherwise comparable populations. ${ }^{53}$ These findings support a more cautious transfusion strategy than the current system. A retrospective study in two US hospitals found a significant correlation between inadequate or suboptimal documentation and failure to justify transfusion, with $73 \%$ of inadequately documented transfusions not meeting hospital guidelines. ${ }^{59}$ Inappropriate transfusion practices may endanger patients and waste resources. A recent RCT demonstrated that a liberal transfusion strategy (a higher $\mathrm{Hb}$ threshold of $10 \mathrm{~g} \mathrm{dl}^{-1}$ ) did not improve outcomes (death, inability to walk independently at a 60 day follow-up and in-hospital mordibity) compared with a restrictive strategy ( $\mathrm{Hb}$ threshold of $<8 \mathrm{~g} \mathrm{dl}^{-1}$ ), in a population of high-risk patients after hip-fracture surgery. ${ }^{60}$

\section{Patient blood management}

The clinical, logistic, and economic disadvantages of RBC transfusion have prompted recommendations for its restriction, particularly unnecessarily transfused stored blood ${ }^{54}$ and an interest in new approaches. 5232437 The concept of PBM (or 'blood conservation') has been developed to promote 'the appropriate provision and use of blood, its components and derivatives, and strategies to reduce or avoid the need for a blood transfusion'. ${ }^{61}$ However, the concept has been developed with more emphasis on preventative measures and improving patient outcome. PBM relies on three key strategies to achieve its goals: optimize the patient's own RBC mass, minimize blood loss, and harness and optimize physiological tolerance of anaemia. $^{24} 27$ Therefore, PBM requires a multidisciplinary, multimodal, individualized strategy for avoiding and controlling blood loss, and to systematically identify, evaluate, and manage anaemia (Fig. 1). ${ }^{62}$ 
1st Pillar

Optimise haemopoiesis
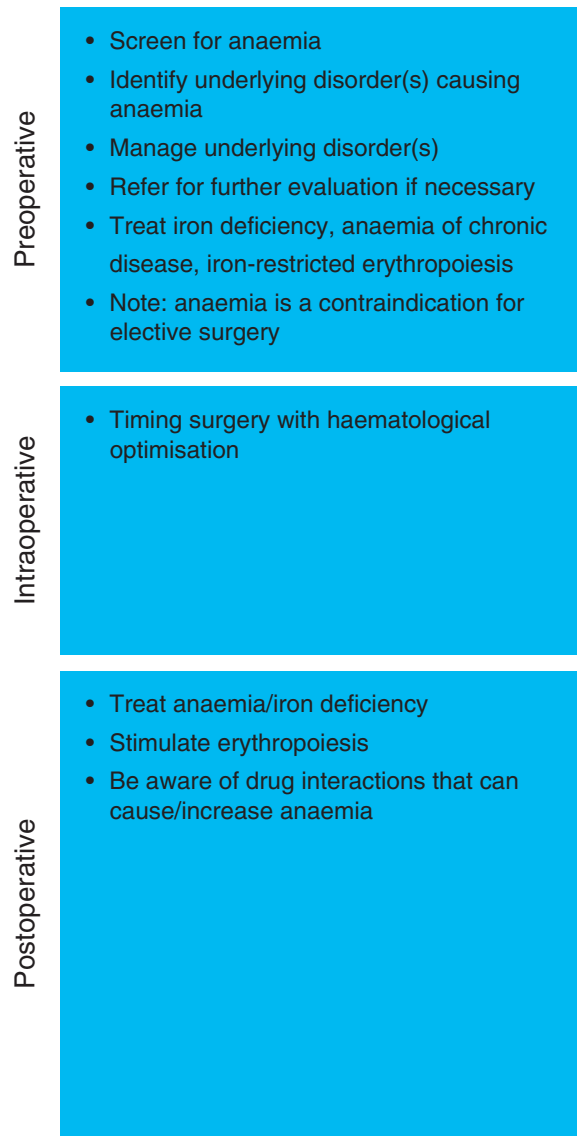

2nd Pillar

Minimise blood loss and bleeding

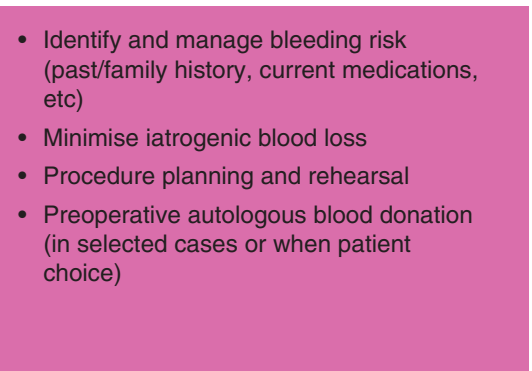

- Meticulous haemostasis and surgical techniques

- Blood-sparing surgical techniques

- Anaesthetic blood-conserving strategies

- Autologous blood options

- Pharmacological/haemostatic agents

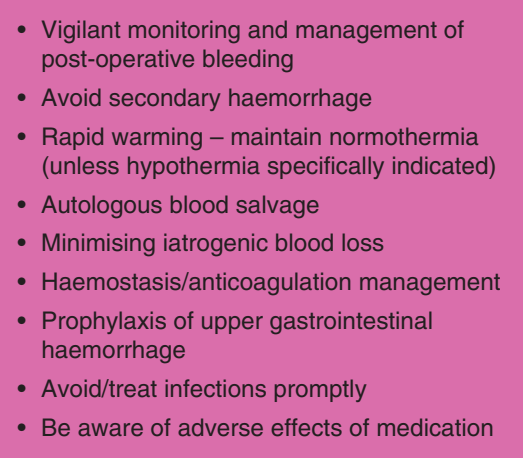

3rd Pillar

Harness and optimise tolerance of anaemia
- Assess/optimise patient's physiological reserve and risk factors

- Compare estimated blood loss with patient-specific tolerable blood loss

- Formulate patient-specific management plan using appropriate blood-conservation modalities to minimise blood loss, optimise red cell mass and manage anaemia

- Restrictive evidence-based transfusion strategies

\section{- Optimise cardiac output \\ - Optimise ventilation and oxygenation \\ - Restrictive evidence-based transfusion strategies}

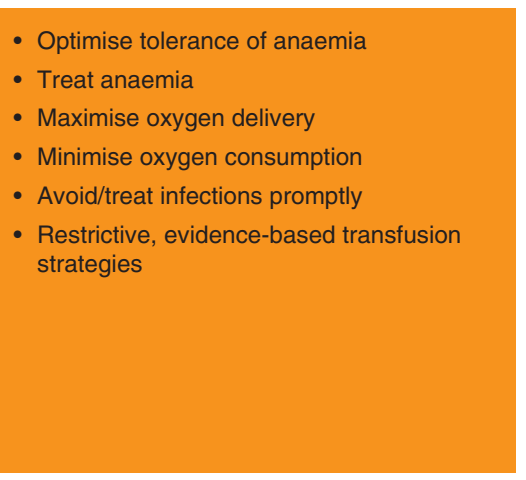

Fig 1 A multimodal approach to PBM (or blood conservation). Adapted from Hofmann and colleagues ${ }^{62}$ with permission. ESA, erythropoiesisstimulating agents.

\section{Perioperative measures}

Before operation, PBM involves a careful assessment of bleeding risk and anaemia well in advance of surgery (e.g. 30 days) to allow full evaluation and correction of anaemia. This has been specifically recommended in patients undergoing orthopaedic surgery. ${ }^{63}$ The patient's own blood should be conserved by restricting blood drawn for tests and by restricting the use of antiplatelet and anticoagulant agents to situations where these drugs are indicated. Pharmacological and mechanical venous thromboembolism prophylaxis measures are both widely used in patients undergoing THR and TKR, with recommendations of better compliance with established evidence-based guidelines. ${ }^{64}$ Autologous preoperative donation was once promoted to decrease the need for ABT. However, predonated blood is also subject to storage lesion, and is labour intensive, expensive, and inefficient, with almost half of predonated autologous units not used. ${ }^{29}$ Some patients may not be able to predonate blood due to comorbidities and current or potential anaemia. ${ }^{3}$
There are possible deleterious effects of blood storage for units predonated weeks ahead of surgery. ${ }^{24}$

It has been suggested that $\mathrm{Hb}$ levels before elective orthopaedic surgery should be within the normal range defined by the World Health Organization (WHO; $\geq 12 \mathrm{~g} \mathrm{dl}^{-1}$ in women; $\geq 13 \mathrm{~g} \mathrm{dl}^{-1}$ in men). ${ }^{61}$ Iron supplementation should be used to correct iron deficiency. Oral iron is effective in reducing the need for transfusion before orthopaedic surgery. ${ }^{65} 66$ Erythropoiesis-stimulating agents (ESAs) may need to be added in patients with preoperative anaemia. ${ }^{66}$ Data from prospective, non-randomized case series suggest that i.v. iron can correct iron deficiency anaemia before elective orthopaedic surgery ${ }^{67}$ and reduce rates of ABT, postoperative infection, and mortality in patients with hip fracture, compared with historical controls. ${ }^{68}{ }^{69}$ Another case series found that the perioperative use of i.v. iron in conjunction with ESA therapy in anaemic patients with hip fracture $(\mathrm{Hb}$ levels of $<13 \mathrm{~g} \mathrm{dl}^{-1}$ ) reduced the proportion of patients requiring transfusion, the number of units transfused, and 
the rate of postoperative infections compared with a parallel control group. There was no difference in the 30 day mortality or the mean duration of hospitalization. ${ }^{70}$ Previous recommendations that patients with preoperative anaemia due to iron deficiency or chronic disease may receive preoperative treatment with i.v. or oral iron, depending on the timing of surgery, the patient's tolerance of oral iron, and iron status, ${ }^{71} 72$ are based on low-to-moderate-quality evidence. Further RCTs of i.v. iron are currently underway.

ESA therapy may be used within PBM strategies. ESA increases $\mathrm{Hb}$ and reduces the need for transfusion in patients undergoing orthopaedic and cardiac surgeries. ${ }^{3} 5246273$ It has been suggested that ESA should be used in anaemic patients in whom iron deficiency anaemia has been ruled out or corrected. ${ }^{63}$ Iron supplementation plus ESA corrected normocytic anaemia due to chronic disease in preoperative orthopaedic surgery patients; ${ }^{10}$ this can lead to increased transfusion avoidance. ${ }^{10}{ }^{74}$ Patients should receive iron supplementation (preferably i.v.) throughout the use of ESA to avoid functional iron deficiency. ${ }^{63} 73$ A recent study evaluated a blood conservation protocol involving a restrictive transfusion trigger $\left(\mathrm{Hb}<8 \mathrm{~g} \mathrm{dl}^{-1}\right)$ and perioperative administration of i.v. iron with $(n=115)$ or without $(n=81)$ ESA in patients undergoing hip fracture repair. ${ }^{75}$ Patients who received ESA therapy together with i.v. iron had a significantly lower allogeneic transfusion rate $(60 \%$ vs $42 \%, P=0.013)$ and higher postoperative $\mathrm{Hb}$ than those who received iron alone, but there was no difference in postoperative complications or 30 day mortality rate. The combination of a restrictive $\mathrm{Hb}$ trigger, i.v. iron, and ESA reduced the use of ABT in patients $(n=139)$ undergoing TKR surgery. ${ }^{76}$ In this study, patients who received unwashed shed blood after operation (if their preoperative $\mathrm{Hb}$ was $<13.0 \mathrm{~g} \mathrm{dl}^{-1}$ ), in addition to ESA and i.v. iron, showed a significantly reduced hospital stay compared with those who received i.v. iron and ESA alone $(P<0.05)$. A more conservative use has been advocated because of concerns about side-effects of ESAs. After regulatory changes in the light of safety concerns, the use of ESA has significantly decreased in cancer centres, but no effect was seen on transfusions. ${ }^{77}$ These changes in usage may impact upon individual PBM strategies, as alternatives to ESA become important.

Intraoperative measures to prevent blood loss include patient positioning and the use of electrocautery, tourniquets, vasoconstrictors, and topical or systemic (e.g. tranexamic acid epsilon aminocaproic acid, aprotinin, and desmopressin) and local haemostatic agents. ${ }^{22} 24 \quad 25$ 78-80 Acute normovolaemic haemodilution, where blood is collected of the operation for potential transfusion after operation and replaced by a crystalloid or colloid solution, can be used to lessen the loss of RBCs and clotting factors during bleeding. Reviews of the use of colloids and crystalloids have shown that while there is no difference in overall patient survival between the two forms, specific products are best suited to certain situations. ${ }^{81}{ }^{82}$ Autologous blood cell salvage is particularly useful for procedures involving massive blood loss and in patients who object to the use of
ABT. Postoperative measures include close monitoring of bleeding and anaemia and the continuing various measures described above. ${ }^{24} 27$ Individual blood conservation approaches may each save $\sim 1-2$ units of blood, and when multiple approaches are used together, 2 units of blood can usually be saved. ${ }^{24} 25$

\section{Implementation and effectiveness of PBM programmes}

A cluster randomization study in Canadian hospitals demonstrated that a multicomponent blood conservation algorithm reduced the use of ABT and increased ESA use in orthopaedic surgery patients. ${ }^{83}$ Similarly, in France, a blood conservation algorithm introduced in one orthopaedic unit in 2005 changed local practice, reducing the overall use of transfusions by $56 \%$ and wastage of autologous blood units by $50 \%(P=0.002)$, and increasing the rate of ESA usage (from 6.6 to $17.3 \% ; P<0.05)$. These changes were associated with a $50 \%$ reduction in hospital costs that offset the costs associated with increased ESA usage, resulting in no significant change in overall costs. ${ }^{84}$

There is increasing awareness of the need to integrate PBM within routine surgical care. PBM has been successfully implemented in some centres in the USA. ${ }^{25}$ The Government of Western Australia has implemented PBM state-wide as the standard of care. ${ }^{80}$ The Australian Red Cross has also issued guidance on measures to reduce the need for $A B T$, including in surgical patients. ${ }^{85}$

\section{Current European PBM practice}

\section{Overview}

The implementation of PBM in Europe has been variable and inconsistent (Tables 1 and 2). While some countries, such as the Netherlands, have been using some PBM strategies for a decade, other countries have adopted few, if any, of these measures. Notably, no widely accepted guidelines exist to aid the process of PBM implementation.

Typically, anaesthetists, surgeons, or both are responsible for the preoperative assessment of anaemia in patients undergoing surgery. However, as in the Netherlands, other healthcare personnel may be included as part of a multidisciplinary approach. Variations exist between countries in the reported or estimated prevalence rates of preoperative anaemia and in the extent to which it is investigated. The timeframes for the preoperative assessment of anaemia appear to vary from 1 day to 6 weeks before surgery. Shorter timeframes restrict the treatment of preoperative anaemia, because of the pressure not to delay surgery. There also appears to be considerable variation in the availability and use of guidelines for preoperative anaemia treatment and transfusion between countries. The reported frequency of transfusion in orthopaedic surgery in hospitals ranges from $<2$ to $\sim 40 \%^{30}$ (Tables 1 and 2).

\section{Austria}

Patterns of blood use in patients undergoing surgery for THR/TKR were documented by the Austrian Benchmark 
Table 1 Estimates of preoperative anaemia prevalence and transfusion rates in orthopaedic surgery patients in selected European countries ESA, erythropoiesis-stimulating agents; Hb, haemoglobin; THR, total hip replacement; TKR, total knee replacement

\begin{tabular}{|c|c|c|}
\hline Country & Prevalence of preoperative anaemia & Frequency of transfusion use \\
\hline Austria & $16-18 \%$ & $\begin{array}{l}\mathrm{TKR}=41.3 \% \text { (varied from } 12 \% \text { to } 87 \% \text { between centres); } \\
\mathrm{THR}=42.5 \% \text { (varied from } 16 \% \text { to } 85 \% \text { between centres); }<10 \% \\
\text { receive predonated autologous blood; patients with anaemia } \\
\text { receive } 2 \times \text { amount of blood received by those without anaemia }\end{array}$ \\
\hline France & Estimate: $\sim 20 \%$ (no precise data) & Estimate: $\sim \mathbf{4 0 \%}$ (despite ESA use) \\
\hline Germany & Not known & Not known \\
\hline Spain & $\begin{array}{l}\text { In general, } 18.3 \% \text { (but almost one-third of patients } \\
\text { have } \mathrm{Hb} \text { levels of }<13 \mathrm{~g} \mathrm{dl}^{-1} \text { ) }\end{array}$ & $\begin{array}{l}\text { Transfusion risk (varies among centres): } \mathrm{Hb} \leq 10 \mathrm{~g} \mathrm{dl}^{-1}: 93.2 \% \text {; } \\
\mathrm{Hb}=14 \mathrm{~g} \mathrm{dl}^{-1}: 19.75 \% ; \mathrm{Hb}=13 \mathrm{~g} \mathrm{dl}^{-1}: 40 \%\end{array}$ \\
\hline Switzerland & Estimates in selected centres: $16-21 \%$ & $\begin{array}{l}\text { Estimates in selected centres: primary repair: } 19-22 \% \text {; repeat } \\
\text { operations: } 30-40 \%\end{array}$ \\
\hline The Netherlands & $\begin{array}{l}\text { Estimate of anaemia ( } \mathrm{Hb} \text { levels of }<13 \mathrm{~g} \mathrm{dl}^{-1} \text { ): } \\
15-20 \% \text { for major orthopaedic surgery }\end{array}$ & $\mathrm{TKR}<2 \% ; \mathrm{THR}<5 \%$ \\
\hline UK & $\begin{array}{l}<12 \mathrm{~g} \mathrm{dl}^{-1} \text { in } 15 \% \text { and }<13 \mathrm{~g} \mathrm{dl}^{-1} \text { in } 37 \% \text { of } \\
\text { patients (within } 28 \text { days of surgery) }\end{array}$ & $\begin{array}{l}57 \% \text { of patients with a preoperative } \mathrm{Hb} \text { level of }<12 \mathrm{~g} \mathrm{dl}^{-1} ; 20 \% \\
\text { of patients with a preoperative } \mathrm{Hb} \text { level of } \geq 12 \mathrm{~g} \mathrm{dl}^{-1}\end{array}$ \\
\hline
\end{tabular}

Study, a prospective observational study in 18 hospitals between 2004 and $2005 .^{29}$ Preoperative anaemia was $\sim 3$-fold more common in patients who received transfusions compared with those who did not receive transfusions (28.6\% vs $6.7 \%$ in patients undergoing THR, $29.9 \%$ vs $9.3 \%$ in TKR, $33.1 \%$ vs $12.6 \%$ in CABG). Variations were observed between centres in the number of RBCs transfused, the use of blood salvage, and the return of shed blood. The second Austrian benchmark study confirmed that anaemic patients received transfusions twice as often as non-anaemic patients, and up to four times as many transfusions (unpublished data; personal communication of H.G., P.H. Rehak, A.S., and A.H.).

There are no national guidelines for the management of preoperative anaemia or transfusion guidelines. However, treatment is guided by algorithms, and includes iron and vitamin B12 supplementation as necessary (Table 2). The transfusion guidelines of the ASA are followed. ${ }^{86}$ PBM strategies are established in only a few hospitals in Austria, and broad implementation is necessary.

\section{France}

$\mathrm{Hb}$ is typically measured 2 or 30 days before operation (Table 1). Preoperative anaemia is not usually investigated further. French guidelines ${ }^{87}$ recommend the use of ESA, with iron supplementation, when $\mathrm{Hb}$ is $\leq 13 \mathrm{~g} \mathrm{dl}^{-1}$, although this is limited predominantly to hip surgery. I.V. iron is indicated for the correction of postoperative anaemia when oral iron is insufficient or not well tolerated. Some institutions customize ESA use, but $\sim 50 \%$ do not treat anaemia before operation.

As described above, at least one report of the successful implementation of a PBM algorithm in France has been published, showing a reduction in transfusions and an increase in the use of ESA with no increase in overall costs. ${ }^{84}$

\section{Germany}

There appears to be limited awareness or appreciation of the problem of preoperative anaemia in this setting in Germany. Anaemia is generally assessed the day before surgery and is usually investigated further if $\mathrm{Hb}$ is $<8 \mathrm{~g} \mathrm{dl}^{-1}$. No preoperative anaemia treatment guidelines exist, and transfusion guidelines are determined locally by hospitals.

\section{Spain}

The risk of transfusion varies according to the patient's level of preoperative anaemia (Table 1). The rate of transfusion in Spain varies significantly between centres and surgical teams; as such, rates for the country as a whole are uncertain. Orthopaedic surgery patients undergo a comprehensive preoperative assessment and, if present, preoperative anaemia is usually investigated further (Table 2).

No specific national guidelines for preoperative anaemia exist, although an algorithm is used where PBM is implemented. ${ }^{88}$ Transfusion is normally recommended for patients with $\mathrm{Hb}<7 \mathrm{~g} \mathrm{dl}^{-1}$, but this threshold can be $<10 \mathrm{~g} \mathrm{dl}^{-1}$ in patients with active bleeding or who are receiving chemotherapy (Table 2 ). ${ }^{89}$

\section{Switzerland}

The prevalence of preoperative anaemia in patients undergoing THR or TKR surgery in Switzerland is $\sim 16-21 \%$ with transfusion rates of $\sim 19-22 \%$ in primary repair surgery and $30-40 \%$ in surgical revisions. ${ }^{67}$ Various laboratory tests, including iron status tests, are performed by primarycare physicians/surgeons in the days or weeks before surgery (Table 2), although less severe anaemia (Hb 10-13 $\mathrm{g} \mathrm{dl}^{-1}$ ) may often be missed. Recommended transfusion triggers depend on the type of surgery (e.g. $\mathrm{Hb}<6 \mathrm{~g} \mathrm{dl}^{-1}$ in obstetrics, $<7 \mathrm{~g} \mathrm{dl}^{-1}$ in general surgery, and $<8 \mathrm{~g} \mathrm{dl}^{-1}$ in 
Table 2 PBM practices in orthopaedic surgery in selected European countries. COX, cyclo-oxygenase; CRP, C-reactive protein; EPO, recombinant human erythropoietin; ESA, erythropoiesis-stimulating agents; Hb, haemoglobin; $\mathrm{MCH}$, mean corpuscular haemoglobin; MCV, mean cell volume; NSAID, non-steroidal anti-inflammatory drugs; PBM, patient blood management; SOC, standard of care; TBC, total blood count; TSAT, transferrin saturation

\begin{tabular}{|c|c|c|c|c|}
\hline Country & $\begin{array}{l}\text { Assessment procedures, } \\
\text { responsible person, and } \\
\text { haematological parameters }\end{array}$ & $\begin{array}{l}\text { If present, is } \\
\text { preoperative anaemia } \\
\text { investigated further? }\end{array}$ & Anaemia management & $\begin{array}{l}\text { Are PBM strategies in place for } \\
\text { major elective surgery? }\end{array}$ \\
\hline \multirow[t]{4}{*}{ Austria } & $\begin{array}{l}\text { Complete preoperative investigation } \\
\text { performed at clinic visit } 4 \text { weeks } \\
\text { before surgery, with preparation for } \\
\text { anaesthesia and implementation of } \\
\text { PBM }\end{array}$ & Yes & $\begin{array}{l}\text { Dependent on algorithm } \\
\text { and laboratory testing }\end{array}$ & Yes, but only in a few hospitals \\
\hline & $\begin{array}{l}\text { Tests: TBC, followed by MCV, } \\
\text { creatinine, ferritin depending on } \mathrm{Hb}\end{array}$ & & $\begin{array}{l}\text { Iron supplementation if } \\
\mathrm{MCV}<80 \mathrm{fl} \text {, ferritin }<100 \\
\text { ng litre }{ }^{-1} \text {, transferrin } \\
\text { saturation }<20 \%\end{array}$ & \\
\hline & & & Vitamin $\mathrm{B} 12$ if $\mathrm{MCV}>100 \mathrm{fl}$ & \\
\hline & & & $\begin{array}{l}\text { Responsible person: } \\
\text { anaesthetist }\end{array}$ & \\
\hline \multirow[t]{4}{*}{ France } & $\begin{array}{l}\text { Patient assessed } 2 \text { days before } \\
\text { operation when no planned } \\
\text { indication for ESA, } 30 \text { days before } \\
\text { operation when ESA planned }\end{array}$ & Usually not & $\begin{array}{l}\text { Usually intra- or } \\
\text { postoperative transfusion } \\
\text { to address anaemia }\end{array}$ & No \\
\hline & $\begin{array}{l}\text { Tests: } \mathrm{Hb} \text { concentration only, } \\
\text { platelet count }\end{array}$ & & $\begin{array}{l}\text { Preoperative transfusion } \\
\text { only when anaemia is } \\
\text { profound or if surgery is } \\
\text { delayed/cancelled (rare) }\end{array}$ & \\
\hline & Responsible person: anaesthetist & & $\begin{array}{l}\text { ESA are used mainly in hip } \\
\text { surgery }\end{array}$ & \\
\hline & & & $\begin{array}{l}\text { Responsible person: } \\
\text { anaesthetist }\end{array}$ & \\
\hline \multirow[t]{3}{*}{ Germany } & $\begin{array}{l}\text { Patients usually assessed the day } \\
\text { before surgery }\end{array}$ & $\begin{array}{l}\text { Usually, if } \mathrm{Hb} \text { level is } \\
<8 \mathrm{~g} \mathrm{dl}^{-1}\end{array}$ & $\begin{array}{l}\text { When transfusion is } \\
\text { performed, erythrocyte } \\
\text { concentrates are usually } \\
\text { given }\end{array}$ & No \\
\hline & $\begin{array}{l}\text { Tests: Hb, haematocrit, platelet } \\
\text { parameters, electrolytes }\end{array}$ & & $\begin{array}{l}\text { Responsible persons: } \\
\text { surgeons (before and after } \\
\text { operation), anaesthetist } \\
\text { (intraoperatively) }\end{array}$ & \\
\hline & Responsible person: surgeon & & & \\
\hline \multirow[t]{5}{*}{ Spain } & $\begin{array}{l}\text { Patients assessed } 4-6 \text { weeks before } \\
\text { surgery (average } 30 \text { days) }\end{array}$ & Usually & $\begin{array}{l}\text { Analysis of patient's } \\
\text { condition }\end{array}$ & Yes, including the following: \\
\hline & $\begin{array}{l}\text { Tests: Hb, reticulocyte count, MCH, } \\
\text { MCV, \% of hypochromic } \\
\text { erythrocytes, vitamin B12, folic acid, } \\
\text { iron indices (ferritin, TSAT). Other } \\
\text { tests include medical history and } \\
\text { bleeding tendency, viral infections, } \\
\text { drugs, previous transfusion, body } \\
\text { weight and height, ASA status, ECG, } \\
\text { X-ray (optional), general lab tests }\end{array}$ & & Analysis of transfusion risk & $\begin{array}{l}\text { Correction with iron and vitamin } \\
\text { supplementation, and ESA before } \\
\text { elective surgery }\end{array}$ \\
\hline & $\begin{array}{l}\text { Anaemia part of systematic protocol } \\
\text { for all major elective orthopaedic } \\
\text { surgery }\end{array}$ & & Review of laboratory tests & $\begin{array}{l}\text { Discontinuation of anticoagulants } \\
\text { and antiplatelet agents before } \\
\text { elective surgery, when this } \\
\text { measure is safe }\end{array}$ \\
\hline & Responsible person: anaesthetist & & Date of surgery considered & $\begin{array}{l}\text { Autologous blood predonation in } \\
\text { complex surgery }\end{array}$ \\
\hline & & & $\begin{array}{l}\text { Responsible person: usually } \\
\text { anaesthetist (in some } \\
\text { cases, haematologist) }\end{array}$ & $\begin{array}{l}\text { Use of better anaesthetic and } \\
\text { surgical techniques to minimize } \\
\text { blood loss during surgery }\end{array}$ \\
\hline
\end{tabular}


Table 2 Continued

$\begin{array}{lll}\text { Country } & \begin{array}{l}\text { Assessment procedures, } \\ \text { responsible person, and } \\ \text { haematological parameters }\end{array} & \begin{array}{l}\text { If present, is } \\ \text { preoperative anaemia } \\ \text { investigated further? }\end{array}\end{array}$

Switzerland

The Netherlands
Lab tests (including Hb, MCV, ferritin, Yes TSAT, and (RP) performed by primary care physician/surgeons days/week before surgery

$\mathrm{Hb}$ measured on the day before surgery
$1-1.5 \mathrm{~g}$ iron carboxymaltose for 'pure' iron deficiency anaemic

40000 units EPO added to i.v. iron for 'combined' forms of anaemia
Blood volume calculation: takes account of patient's blood volume, $\mathrm{Hb}$ transfusion trigger, and expected blood loss based on each centre's data

Responsible person: anaesthetist and surgeon
All: $1 \mathrm{mg}$ vitamin B12 i.m (once); $3 \times 5 \mathrm{mg}$ folic acid (oral)

Patients re-evaluated after 2 weeks, redoes i.v. iron and EPO: CAVE Hb should not become $>15 \mathrm{~g} \mathrm{dl}^{-1}$

Responsible person: in the future-anaesthetist (and surgeon) with GP

By law, a preoperative assessment must be performed (3-4 weeks (3-4 weeks before surgery): medical and/or MCV $<80 \mathrm{fl}$ : history, physical exam, drug history, further investigation laboratory tests ( $\mathrm{Hb}$ and $\mathrm{MCV}$ ) and referral to internal medicine

Responsible person: anaesthetist, nurse anaesthetist, resident surgeon, pharmacy assistant
Surgery cancelled until outcome known before surgery)

Inspected by Health Authority every year

NEN-EN-ISO 9001: 2000 certified

Expected blood loss for surgery calculated (0.5-1.5 litre total loss in hip/knee surgery)

Patients with $\mathrm{Hb}$ of $10-13$ $\mathrm{g} \mathrm{dl}^{-1}$ received ESA plus iron

Responsible person: anaesthetist
Are PBM strategies in place for major elective surgery?

Use of pharmacological strategies with proven efficacy

Optimal control of coagulation

Minimize blood sample extractions for laboratory use Intraoperative blood collection and reinfusion of blood loss during surgery

Yes, in limited number of hospitals

University Hospital of Zurich: introduction of PBM in orthopaedic surgery has been agreed, including change in logistics to see all patients (surgeons and anaesthesiologist) 4 weeks before surgery. Coagulation management and perioperative thromboembolic prophylaxis in discussion, with a governmental grant received

Yes (over last $10 \mathrm{yr}$ )

Preoperative: ESA, COX-2-selective NSAIDs

Perioperative: surgery technique, temperature, transfusion trigger

Postoperative: cell-saving

(Bellovac ${ }^{\mathrm{TM}} \mathrm{ABT}$ ), transfusion trigger 
Table 2 Continued

\begin{tabular}{lllll} 
Country & $\begin{array}{l}\text { Assessment procedures, } \\
\text { responsible person, and } \\
\text { haematological parameters }\end{array}$ & $\begin{array}{l}\text { If present, is } \\
\text { preoperative anaemia } \\
\text { investigated further? }\end{array}$ & Anaemia management & $\begin{array}{l}\text { Are PBM strategies in place for } \\
\text { major elective surgery? }\end{array}$ \\
\hline UK & $\begin{array}{l}\text { Preoperative clinic scheduled 2-6 } \\
\text { weeks before all elective surgery }\end{array}$ & $\begin{array}{l}\text { Usually not. If } \\
\text { unexpected anaemia } \\
\text { identified patient } \\
\text { referred back to general } \\
\text { practitioner for } \\
\text { investigation }\end{array}$ & $\begin{array}{l}\text { Patient cross-matched for } \\
\text { anticipated blood } \\
\text { transfusion requirement }\end{array}$ & Some centres now developing \\
pilot studies on PBM in the UK
\end{tabular}

Tests: Hb electrolytes, ECG, or per departmental/procedural protocol. Complex patients identified from clinic are seen in pre-assessment by anaesthetists.

Investigation of anaemia not part of current SOC

Protocols established to withhold anticoagulation and antiplatelet therapy before operation

Intraoperative cell salvage used in major non-oncological surgery

Tranexamic acid increasingly used in significant haemorrhage

traumatic brain injury) and on the stability of the patient. PBM strategies are in place in a limited number of hospitals.

\section{The Netherlands}

Dutch hospitals began to implement PBM $\sim 10 \mathrm{yr}$ ago, especially for major orthopaedic surgery (Table 2). There is a legal requirement for a complete preoperative assessment 3-4 weeks before all elective surgery. Importantly, anaesthetists can cancel surgery until the outcome of treatment for anaemia is known. Preoperative PBM precautions include the use of cyclooxygenase-2-selective non-steroidal antiinflammatory drugs to reduce the risk of bleeding after taking known risk factors into consideration. ${ }^{90-93}$ The introduction of ESA use for patients undergoing other surgery types is likely to occur in the future. National transfusion triggers were instituted in 2000 (e.g. $\mathrm{Hb}$ of $6.4 \mathrm{~g} \mathrm{dl}^{-1}$ for normal healthy patients).

All hospitals in the Netherlands report transfusion rates in knee and hip surgery, and these can be compared on the central website of the Dutch Health Authority. ${ }^{94}$ The results of national surveys of Dutch orthopaedic surgery departments performed in 2002 and 2007 have documented the increasing use of PBM measures to avoid transfusion. ${ }^{95}$ The use of preoperative autologous blood donation was similar in 2002 and 2007 for both hip and knee arthroplasty (Fig. 2). However, the preoperative use of ESA approximately doubled between 2002 and 2007, while the use of postoperative autologous cell salvage increased by 4 - to 5 -fold. Smaller increases were observed in the use of intraoperative autologous cell salvage.

Annual reports from the Dutch blood bank Sanquin ${ }^{96}$ showed a decline in the total number of allogeneic transfusions by $12 \%$ in the period from the year 2000 to 2009 (Fig. 3). This decrease was concurrent with an increase in healthcare usage. Hospital admissions increased from 1600

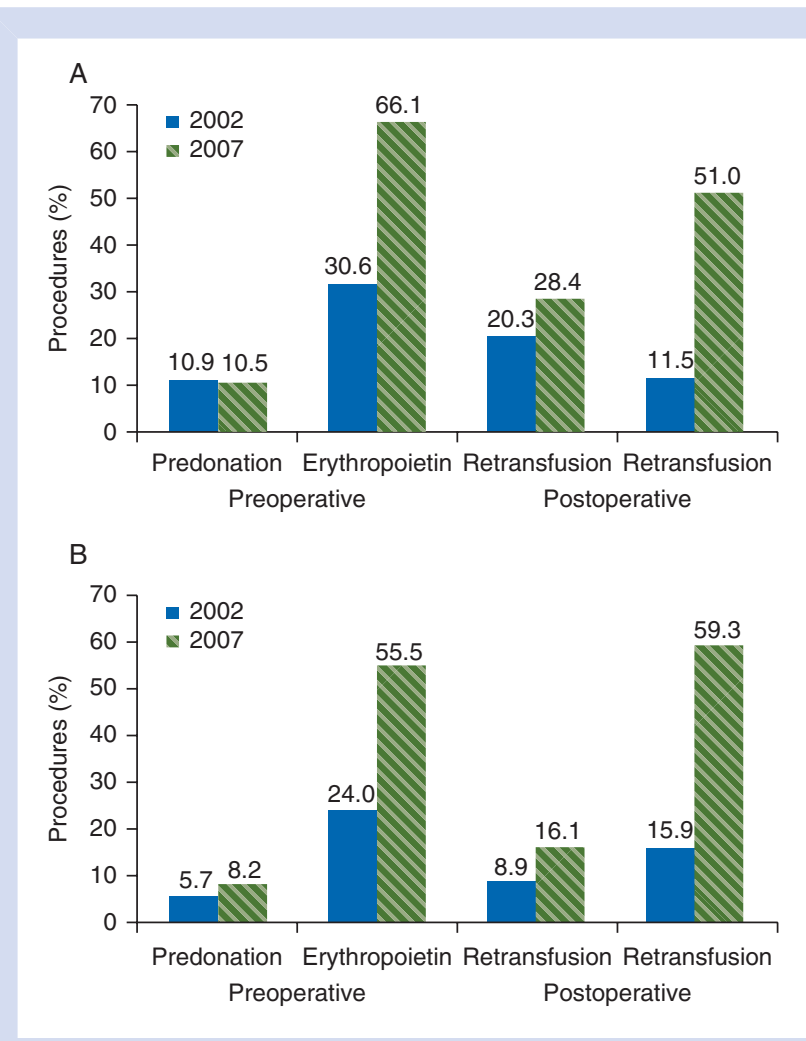

Fig 2 Results of a national survey of rates of autologous preoperative blood donation, erythropoietin use, and autologous retransfusion in patients undergoing (A) hip or (B) knee arthroplasty in 2002 and 2007 in the Netherlands. ${ }^{91}$

to 2300 per year per 10000 inhabitants from 2000 to 2009 . Based on the current price of an allogeneic transfusion of RBCs at $€ 204$, PBM is estimated to have saved a net cost of $€ 100$ million nationwide every year. 


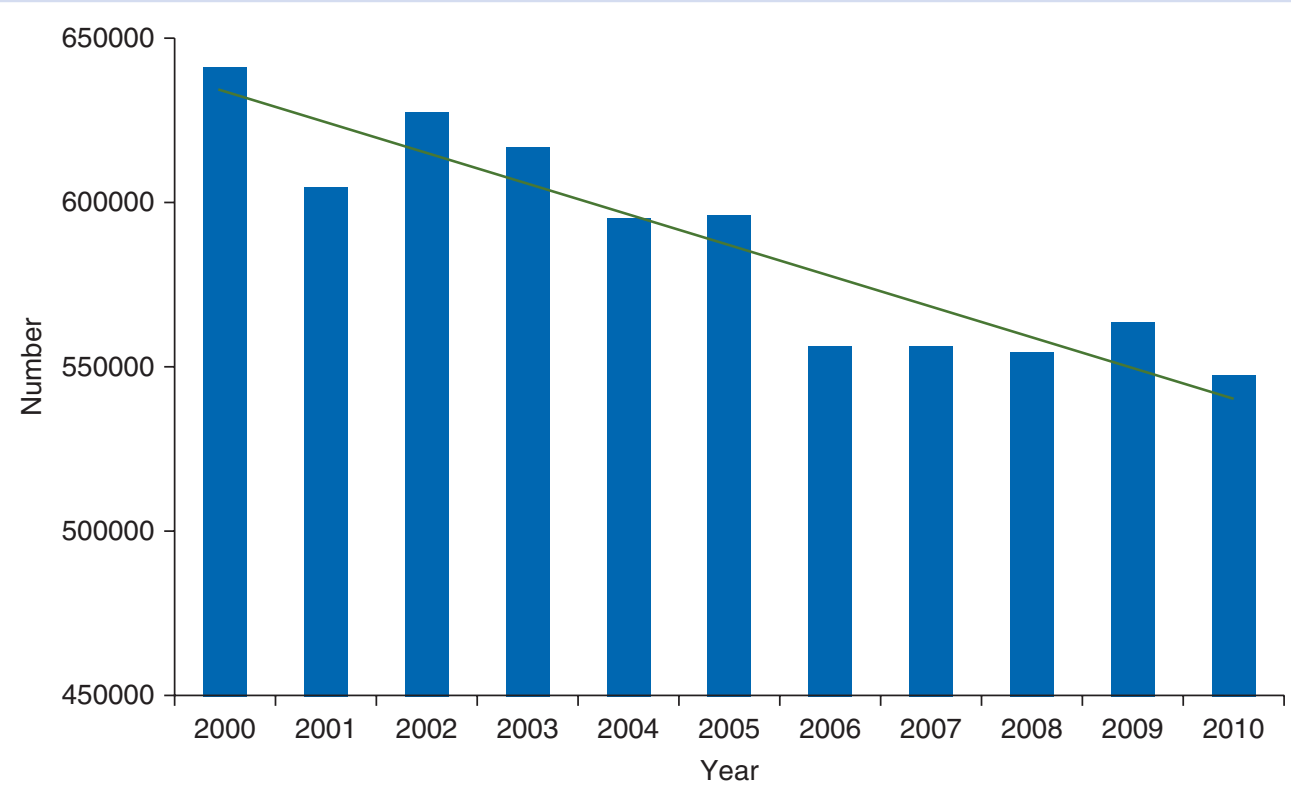

Fig 3 Number of allogeneic transfusions in the Netherlands from 2000 to $2010 .^{96}$

\section{United Kingdom}

In the UK, elective surgery patients attend a pre-admission clinic for review 2-6 weeks before operation where routine health checks and blood tests, ECG, and, where appropriate, anaesthetic review are undertaken. ${ }^{97}$ The aim of pre-assessment is to reduce hospital stay by facilitating admission on the day of operation, and to reduce the risk of operative cancellations (Table 2). An internal audit at one UK centre prospectively reviewed all patients admitted for elective operation over a 4 month period. Of 1532 patients seen in all specialties, preoperative anaemia was present in 252 (16\%). Most patients had a normocytic normochromic pattern with one-third having iron deficiency (ferritin $<30 \mathrm{ng}$ litre ${ }^{-1}$ with hypochromia or microcytosis). The perioperative transfusion rate was $26 \%$ in anaemic patients and $5 \%$ in those with normal $\mathrm{Hb}$ levels. Both preoperative anaemia and transfusion were associated with increased length of hospital stay.

A national comparative audit of blood use in elective primary THR surgery was conducted in the UK in 2006-7.98 Data on 7465 patients from 225 hospitals were analysed. Almost all of the participating hospitals performed preoperative anaemia assessments, although $29 \%$ of patients did not have a presurgery $\mathrm{Hb}$ level recorded. Fewer than half of the hospitals $(47 \%)$ had a transfusion policy. Overall, $25 \%$ of patients were transfused within the period from 28 days presurgery to 14 days postsurgery, but this figure varied from $0 \%$ to $100 \%$ between hospitals. Data from pilot studies suggested that PBM in anaemic patients before primary joint replacement or major abdominal surgery may reduce the need for RBC transfusion by $30-40 \%$. Translating these projections to the National Health Service (NHS), 60500 major operations and 119600 primary THR and TKR procedures were projected. A reduction in RBC transfusion alone would translate into the NHS saving $£ 3782552$, reducing hospital stay by 1 day in $4.51 \%$ would equate to a saving of $£ 14.3$ million, and complications could be prevented in 5397 patients, saving $£ 17.1$ million. Overall, PBM could produce a conservative annual saving of $\sim £ 35$ million to the NHS. As the audit is now several years old, it is worth noting that some of these improvements and savings may have already been made. An RCT is under consideration by the National Institute for Health Research in the UK to further assess the findings from these pilot studies.

A wider implementation of PBM within perioperative care in European countries may be hindered by a variety of potential barriers. This group recommends that authorities responsible for PBM implementation consider these barriers in conjunction with a variety of recommendations to enable an efficient implementation across Europe (Table 3).

In conclusion, there is an urgent need for European healthcare providers to fully recognize the deleterious effects of preoperative anaemia and the risks associated with perioperative blood transfusion, and to integrate multimodal PBM strategies into routine care for patients undergoing orthopaedic and other types of surgery. Implementing PBM requires a paradigm shift in preoperative care whereby anaemia is detected well in advance of elective surgery and treated using effective measures that reduce the requirement for blood transfusion and improve the quality of care. Transfusion should be the last option in the treatment of anaemia, rather than the first choice. The implementation of PBM requires liaison and partnership between all personnel and organizations responsible for perioperative care, including Blood Service authorities. 
Table 3 Barriers to, and recommendations for, the implementation of PBM in Europe

Barriers to implementation of PBM
Surgeons may not fully understand the clinical impact of anaemia
(including iron deficiency anaemia) and the effect of anaemia on
postoperative recovery

Doctors, familiar with the ease and established use of blood transfusion, may not appreciate the risks associated with transfusions or the role of a restrictive transfusion practice (PBM)

There is a lack of a standardized, accepted definition of preoperative anaemia, and a paucity of widely accepted evidence-based PBM guidelines/recommendations

Patients often present at hospital for surgery without an early preoperative assessment to allow the evaluation and correction of anaemia

There could be concerns that PBM may delay surgery (particularly cardiac surgery)

There could be concerns that PBM may increase the risk of complications

There is currently no RCT to support the use of PBM in elective surgery

Further data confirming the cost-effectiveness of PBM programmes are required

Individual hospital departments may fear the initial costs of implementing PBM, even though PBM is expected to reduce longer-term healthcare costs through lower direct expenditure, reduced complications, and shorter hospitalization times

In some countries, the use of i.v. iron is not reimbursed (or its reimbursement is limited to certain surgical indications), while each transfusion is separately reimbursed

In some countries, the established position of the blood services system in hospitals and government may limit the scope for changes in the management of blood components

There is a lack of trained personnel with expertise in PBM

The routine use of transfusion is a 'habit' and change is therefore limited by clinical inertia

The personal benefit PBM offers to physicians is not well appreciated

\section{Recommendations for implementation of PBM}

There is a need to increase knowledge and awareness of the clinical implications of anaemia and the need for alternatives to transfusion, with a focus on clinical outcomes, inappropriateness, cost, and supply issues

Further high-quality data confirming the effectiveness of PBM programmes in reducing complications and mortality, and the cost-effectiveness of these programmes, are required

Standardized algorithms for the definition and treatment of preoperative anaemia in elective surgery are required to avoid a reliance solely on $\mathrm{Hb}$ levels as a trigger. This is supported by findings from OSTHEO, in which accurate assessment of preoperative $\mathrm{Hb}$ levels was found to contribute to effective blood and anaemia management ${ }^{25}$

Early preoperative visits should be scheduled, in order to allow preoperative anaemia to be corrected before surgery

There is a need to encourage a paradigm shift among physicians, with a focus on the reporting of data on transfusion rates and patient outcomes to encourage 'healthy competition' between institutions

Documentation processes for PBM (including improved consent forms for blood transfusion for example) are required

Incentives for the use of newer measures, and disincentives against older practices, are required to ensure the implementation of PBM. The benefits of PBM for healthcare professionals, in terms of personal accomplishment, should also be communicated

Development of 'centres of excellence' for PBM, including clinical champions

Creation of PBM registries for systematic data collection and evaluation

The reimbursement system should favour the use of PBM measures, including early anaemia detection and treatment
Currently, the implementation of PBM in Europe is limited, and considerable variations exist in the assessment and treatment of preoperative anaemia. Lessons can be learned from countries and centres where PBM has already been integrated into routine practice, for example, in the USA, Western Australia, and in the Netherlands. It is hoped that this report also aids the wider implementation of PBM in Europe.

\section{Declaration of interest}

A.H. is currently receiving grant support from the Federal Austrian Ministry of Health and the Western Australian Department of Health. In addition, in the past $5 \mathrm{yr}$, he has received honoraria or travel support for consulting or lecturing from the following companies and legal entities: Amgen $\mathrm{GmbH}$, Switzerland; Australian Red Cross Blood Service, Brisbane, Australia; CSL Behring GmbH, Marburg, Deutschland; Dynabyte $\mathrm{GmbH}$, Munich, Germany; Fresenius Kabi GmbH, Bad Homburg, Germany; Haemonetics GmbH, Munich, Germany; Janssen-Cilag $\mathrm{GmbH}$, Austria; Johnson \& Johnson Ethicon Biosurgery, USA; Novo Nordisk A/S, Bagsvärd, Denmark; Pentapharm/TEM GmbH, Germany; United Biosource Corporation, Bethesda, MD, USA; and Vifor Pharma Ltd, Glattbrugg, Switzerland. R.K.'s department is participating in studies for which reimbursements are paid to the university hospital. He has received geographical travel support for consultancy from Bayer, Synthes, Globus Medical, Vifor, Ipsen, and Corim in the past 5 yr. S.L. has received funding for his laboratory work from Vifor. T.R. 
discloses that University College London received a research grant from Vifor in 2009 and that he received a Health Foundation SHINE award for innovation to investigate the problem of anaemia in surgery and potential solutions. D.S.'s academic department is receiving grant support from the Swiss National Science Foundation, Berne, Switzerland (grant numbers: 33CM30_124117 and 406440-131268), the Swiss Society of Anesthesiology and Reanimation (SGAR), Berne, Switzerland (no grant numbers are attributed), the Swiss Foundation for Anesthesia Research, Zurich, Switzerland (no grant numbers are attributed), Bundesprogramm Chancengleichheit, Berne, Switzerland (no grant numbers are attributed), CSL Behring, Berne, Switzerland (no grant numbers are attributed), and Vifor SA, Villars-sur-Giäne, Switzerland (no grant numbers are attributed). D.S. was the chairman of the $A B C$ Faculty and is a member of the $A B C$ Trauma Faculty which both are managed by Thomson Physicians World $\mathrm{GmbH}$, Mannheim, Germany, and sponsored by an unrestricted educational grant from Novo Nordisk AIS, Bagsvärd, Denmark, and CSL Behring $\mathrm{GmbH}$, Hattersheim am Main, Germany. In the past $5 \mathrm{yr}$, D.S. has received honoraria or travel support for consulting or lecturing from the following companies: Abbott AG, AstraZeneca AG, Bayer (Schweiz) AG, Baxter S.p.A., B. Braun Melsungen AG, Boehringer Ingelheim (Schweiz), Bristol-Myers-Squibb, CSL Behring $\mathrm{GmbH}$, Curacyte AG, Ethicon Biosurgery, Fresenius SE, Galenica AG (including Vifor SA), GlaxoSmithKline $\mathrm{GmbH} \&$ Co. KG, Janssen-Cilag AG, Janssen-Cilag EMEA, Merck Sharp \& Dohme-Chibret AG, Novo Nordisk, Octapharma AG, Organon AG, Oxygen Biotherapeutics, Pentapharm GmbH (now tem Innovations), Roche Pharma (Schweiz) AG, and ScheringPlough International, Inc.

\section{Funding}

This study is based on discussions held at an expert panel meeting funded by Vifor Pharma Ltd, Switzerland. The authors acknowledge medical writing support funded by Vifor Pharma Ltd and provided by Prism Ideas (Nantwich, Cheshire, UK). Vifor Pharma Ltd is funding the open access.

\section{References}

1 World Health Organisation. Worldwide prevalence of anaemia 1993-2005. 2008

2 World Health Organisation. The World Health Report 2002: reducing risks, promoting healthy life. 2002

3 Shander A, Knight K, Thurer R, Adamson J, Spence R. Prevalence and outcomes of anemia in surgery: a systematic review of the literature. Am J Med 2004; 116(Suppl. 7A): 58S-69S

4 Keating EM, Meding JB, Faris PM, Ritter MA. Predictors of transfusion risk in elective knee surgery. Clin Orthop Relat Res 1998; 357: 50-9

5 Spahn DR. Anemia and patient blood management in hip and knee surgery: a systematic review of the literature. Anesthesiology 2010; 113: 482-95

6 Kurtz SM, Ong KL, Lau E, et al. International survey of primary and revision total knee replacement. Int Orthop 2011; 35: 1783-9
7 Sehat KR, Evans RL, Newman JH. Hidden blood loss following hip and knee arthroplasty. Correct management of blood loss should take hidden loss into account. J Bone Joint Surg Br 2004; 86: 561-5

8 Karkouti K, Wijeysundera DN, Beattie WS. Risk associated with preoperative anemia in cardiac surgery: a multicenter cohort study. Circulation 2008; 117: 478-84

9 Goodnough LT, Vizmeg K, Sobecks R, Schwarz A, Soegiarso W. Prevalence and classification of anemia in elective orthopedic surgery patients: implications for blood conservation programs. Vox Sang 1992; 63: 90-5

10 Saleh E, McClelland DB, Hay A, Semple D, Walsh TS. Prevalence of anaemia before major joint arthroplasty and the potential impact of preoperative investigation and correction on perioperative blood transfusions. Br J Anaesth 2007; 99: 801-8

11 Carson JL, Poses RM, Spence RK, Bonavita G. Severity of anaemia and operative mortality and morbidity. Lancet 1988; 1: 727-9

12 Carson JL, Duff A, Poses RM, et al. Effect of anaemia and cardiovascular disease on surgical mortality and morbidity. Lancet 1996; 348: 1055-60

13 Musallam KM, Tamim HM, Richards T, et al. Preoperative anaemia and postoperative outcomes in non-cardiac surgery: a retrospective cohort study. Lancet 2011; 378: 1396-407

14 Gruson KI, Aharonoff GB, Egol KA, Zuckerman JD, Koval KJ. The relationship between admission hemoglobin level and outcome after hip fracture. J Orthop Trauma 2002; 16: 39-44

15 Foss NB, Kristensen MT, Kehlet H. Anaemia impedes functional mobility after hip fracture surgery. Age Ageing 2008; 37: 173-8

16 Halm EA, Wang JJ, Boockvar K, et al. The effect of perioperative anemia on clinical and functional outcomes in patients with hip fracture. J Orthop Trauma 2004; 18: 369-74

17 Beattie WS, Karkouti K, Wijeysundera DN, Tait G. Risk associated with preoperative anemia in noncardiac surgery: a single-center cohort study. Anesthesiology 2009; 110: 574-81

18 Wu WC, Schifftner TL, Henderson WG, et al. Preoperative hematocrit levels and postoperative outcomes in older patients undergoing noncardiac surgery. J Am Med Assoc 2007; 297: 2481-8

19 Myers E, O'Grady P, Dolan AM. The influence of preclinical anaemia on outcome following total hip replacement. Arch Orthop Trauma Surg 2004; 124: 699-701

20 Lawrence VA, Silverstein JH, Cornell JE, Pederson T, Noveck H, Carson JL. Higher Hb level is associated with better early functional recovery after hip fracture repair. Transfusion 2003; 43: 1717-22

21 van Straten $A H$, Hamad MA, van Zundert AJ, Martens EJ, Schonberger JP, de Wolf AM. Preoperative hemoglobin level as a predictor of survival after coronary artery bypass grafting: a comparison with the matched general population. Circulation 2009; 120: 118-25

22 Shander A, Goodnough LT. Why an alternative to blood transfusion? Crit Care Clin 2009; 25: 261-77

23 Vamvakas EC, Blajchman MA. Transfusion-related mortality: the ongoing risks of allogeneic blood transfusion and the available strategies for their prevention. Blood 2009; 113: 3406-17

24 Goodnough LT, Shander A. Blood management. Arch Pathol Lab Med 2007; 131: 695-701

25 Shander A, Goodnough LT. Objectives and limitations of bloodless medical care. Curr Opin Hematol 2006; 13: 462-70

26 Rosencher N, Kerkkamp HE, Macheras G, et al. Orthopedic Surgery Transfusion Hemoglobin European Overview (OSTHEO) study: blood management in elective knee and hip arthroplasty in Europe. Transfusion 2003; 43: 459-69 
27 Stanworth SJ, Cockburn HA, Boralessa H, Contreras M. Which groups of patients are transfused? A study of red cell usage in London and southeast England. Vox Sang 2002; 83: 352-7

28 Wells AW, Mounter PJ, Chapman CE, Stainsby D, Wallis JP. Where does blood go? Prospective observational study of red cell transfusion in north England. Br Med J 2002; 325: 803

29 Bierbaum BE, Callaghan JJ, Galante JO, Rubash HE, Tooms RE, Welch RB. An analysis of blood management in patients having a total hip or knee arthroplasty. J Bone Joint Surg Am 1999; 81: 2-10

30 Gombotz H, Rehak PH, Shander A, Hofmann A. Blood use in elective surgery: the Austrian benchmark study. Transfusion 2007; 47: $1468-80$

31 Napolitano LM, Corwin HL. Efficacy of red blood cell transfusion in the critically ill. Crit Care Clin 2004; 20: 255-68

32 Vincent JL, Sakr Y, De Backer D, Van der Linden P. Efficacy of allogeneic red blood cell transfusions. Best Pract Res Clin Anaesthesiol 2007; 21: 209-19

33 Carson JL, Altman DG, Duff A, et al. Risk of bacterial infection associated with allogeneic blood transfusion among patients undergoing hip fracture repair. Transfusion 1999; 39: 694-700

34 Innerhofer P, Klingler A, Klimmer C, Fries D, Nussbaumer W. Risk for postoperative infection after transfusion of white blood cellfiltered allogeneic or autologous blood components in orthopedic patients undergoing primary arthroplasty. Transfusion 2005; 45: $103-10$

35 Newman JH, Bowers M, Murphy J. The clinical advantages of autologous transfusion. A randomized, controlled study after knee replacement. J Bone Joint Surg Br 1997; 79: 630-2

36 Weber EW, Slappendel R, Prins $M H$, van der Schaaf DB, Durieux ME, Strumper D. Perioperative blood transfusions and delayed wound healing after hip replacement surgery: effects on duration of hospitalization. Anesth Analg 2005; 100: 1416-21

37 Shander A, Moskowitz DM, Javidroozi M. Blood conservation in practice: an overview. Br J Hosp Med (Lond) 2009; 70: 16-21

38 Surgenor SD, Kramer RS, Olmstead EM, et al. The association of perioperative red blood cell transfusions and decreased long-term survival after cardiac surgery. Anesth Analg 2009; 108: 1741-6

39 Knowles S, Cohen H, Watt A, Poles D, Jones H, Davies T. The 2010 annual SHOT report. 2011

40 Food and Drug Administration. Fatalities reported to FDA following blood collection and transfusion: annual summary for Fiscal Year 2009. 2009

41 Chaiwat O, Lang JD, Vavilala MS, et al. Early packed red blood cell transfusion and acute respiratory distress syndrome after trauma. Anesthesiology 2009; 110: 351-60

42 Silliman CC. The two-event model of transfusion-related acute lung injury. Crit Care Med 2006; 34: S124-31

43 Triulzi DJ. Transfusion-related acute lung injury: current concepts for the clinician. Anesth Analg 2009; 108: 770-6

44 Sparrow RL. Red blood cell storage and transfusion-related immunomodulation. Blood Transfus 2010; 8: s26-30

45 Isbister JP, Shander A, Spahn DR, Erhard J, Farmer SL, Hofmann A. Adverse blood transfusion outcomes: establishing causation. Trans Med Rev 2011; 25: 89-101

46 Vamvakas EC. Establishing causation in transfusion medicine and related tribulations. Trans Med Rev 2011; 25: 81-8

47 Zimrin $A B$, Hess JR. Current issues relating to the transfusion of stored red blood cells. Vox Sang 2009; 96: 93-103

48 Koch CG, Li L, Sessler DI, et al. Duration of red-cell storage and complications after cardiac surgery. N Engl J Med 2008; 358: 1229-39
49 Weinberg JA, McGwin G Jr, Marques MB, et al. Transfusions in the less severely injured: does age of transfused blood affect outcomes? J Trauma 2008; 65: 794-8

50 Yap CH, Lau L, Krishnaswamy M, Gaskell M, Yii M. Age of transfused red cells and early outcomes after cardiac surgery. Ann Thorac Surg 2008; 86: 554-9

51 Vamvakas EC. Meta-analysis of clinical studies of the purported deleterious effects of 'old' (versus 'fresh') red blood cells: are we at equipoise? Transfusion 2010; 50: 600-10

52 American Association of Blood Banks, America's Blood Centers, American Red Cross. Circular of information for the use of human blood and blood components. 2002. Available from http:// www.fda.gov/downloads/BiologicsBloodVaccines/Guidance ComplianceRegulatoryInformation/Guidances/Blood/UCM155749. pdf (accessed 4 October 2011)

53 Shander A, Fink A, Javidroozi M, et al. Appropriateness of allogeneic red blood cell transfusion: the international consensus conference on transfusion outcomes. Transfus Med Rev 2011; 25: 232 - 46

54 Society for the Advancement of Blood Management (SABM). Blood transfusion and outcomes: international panel of experts finds little evidence for transfusions improving health. 2009. Available from http://www.sabm.org/media/release0409.php (accessed 4 October 2011)

55 Shander A, Hofmann A, Gombotz H, Theusinger OM, Spahn DR. Estimating the cost of blood: past, present, and future directions. Best Pract Res Clin Anaesthesiol 2007; 21: 271-89

56 Shander A, Hofmann A, Ozawa S, Theusinger OM, Gombotz H, Spahn DR. Activity-based costs of blood transfusions in surgical patients at four hospitals. Transfusion 2010; 50: 753-65

57 Boseley S, Topping A. New deal urged for blood scandal victims. 2009. Available from http://www.guardian.co.uk/society/2009/ feb/23/haemophilia-blood-hiv-hepatitis (accessed 4 October 2011)

58 Weinberg PD, Hounshell J, Sherman LA, et al. Legal, financial, and public health consequences of HIV contamination of blood and blood products in the 1980 s and 1990s. Ann Intern Med 2002; 136: $312-9$

59 Friedman MT, Ebrahim A. Adequacy of physician documentation of red blood cell transfusion and correlation with assessment of transfusion appropriateness. Arch Pathol Lab Med 2006; 130: 474-9

60 Carson JL, Terrin ML, Noveck H, et al. Liberal or restrictive transfusion in high-risk patients after hip surgery. N Engl J Med 2011; 365: $2453-62$

61 Society for the Advancement of Blood Management. About SABM. 2010. Available from http://www.sabm.org/about/ (accessed 4 October 2011)

62 Hofmann A, Friedman D, Farmer S, The Western Australian Department of Health. Western Australian patient blood management project. Available from http://www.health.wa.gov.au/ bloodmanagement/docs/pbm_pillars.pdf (accessed 4 October 2011)

63 Goodnough LT, Maniatis A, Earnshaw P, et al. Detection, evaluation, and management of preoperative anaemia in the elective orthopaedic surgical patient: NATA guidelines. Br J Anaesth 2011; 106: $13-22$

64 Friedman RJ, Gallus A, Gil-Garay E, FitzGerald G, Cushner F. Practice patterns in the use of venous thromboembolism prophylaxis after total joint arthroplasty-insights from the Multinational Global Orthopaedic Registry (GLORY). Am J Orthop (Belle Mead NJ) 2010; 39(9 Suppl): 14-21

65 Andrews CM, Lane DW, Bradley JG. Iron pre-load for major joint replacement. Transfus Med 1997; 7: 281-6 
66 Cuenca J, Garcia-Erce JA, Martinez F, Cardona R, Perez-Serrano L, Munoz M. Preoperative haematinics and transfusion protocol reduce the need for transfusion after total knee replacement. Int J Surg 2007; 5: 89-94

67 Theusinger OM, Leyvraz PF, Schanz U, Seifert B, Spahn DR. Treatment of iron deficiency anemia in orthopedic surgery with intravenous iron: efficacy and limits: a prospective study. Anesthesiology 2007; 107: 923-7

68 Cuenca J, Garcia-Erce JA, Munoz M, Izuel M, Martinez AA, Herrera A. Patients with pertrochanteric hip fracture may benefit from preoperative intravenous iron therapy: a pilot study. Transfusion 2004; 44: 1447-52

69 Cuenca J, Garcia-Erce JA, Martinez AA, Solano VM, Molina J, Munoz M. Role of parenteral iron in the management of anaemia in the elderly patient undergoing displaced subcapital hip fracture repair: preliminary data. Arch Orthop Trauma Surg 2005; 125: 342-7

70 Garcia-Erce JA, Cuenca J, Munoz M, et al. Perioperative stimulation of erythropoiesis with intravenous iron and erythropoietin reduces transfusion requirements in patients with hip fracture. A prospective observational study. Vox Sang 2005; 88: 235-43

71 Beris P, Munoz M, Garcia-Erce JA, Thomas D, Maniatis A, Van der Linden P. Perioperative anaemia management: consensus statement on the role of intravenous iron. $\mathrm{Br} J$ Anaesth 2008; 100: 599-604

72 Munoz M, Breymann C, Garcia-Erce JA, Gomez-Ramirez S, Comin J, Bisbe E. Efficacy and safety of intravenous iron therapy as an alternative/adjunct to allogeneic blood transfusion. Vox Sang 2008; 94: 172-83

73 Weltert L, D'Alessandro S, Nardella S, et al. Preoperative very short-term, high-dose erythropoietin administration diminishes blood transfusion rate in off-pump coronary artery bypass: a randomized blind controlled study. J Thorac Cardiovasc Surg 2010; 139: $621-6$

74 Auerbach M, Goodnough LT, Picard D, Maniatis A. The role of intravenous iron in anemia management and transfusion avoidance. Transfusion 2008; 48: 988-1000

75 Garcia-Erce JA, Cuenca J, Haman-Alcober S, Martinez AA, Herrera A, Munoz M. Efficacy of preoperative recombinant human erythropoietin administration for reducing transfusion requirements in patients undergoing surgery for hip fracture repair. An observational cohort study. Vox Sang 2009; 97: 260-7

76 Cuenca J, Garcia-Erce JA, Martinez F, Perez-Serrano L, Herrera A, Munoz M. Perioperative intravenous iron, with or without erythropoietin, plus restrictive transfusion protocol reduce the need for allogeneic blood after knee replacement surgery. Transfusion 2006; 46: 1112-9

77 Vadhan-Raj S, Zhou X, Sizer K, et al. Impact of safety concerns and regulatory changes on the usage of erythropoiesis-stimulating agents and RBC transfusions. Oncologist 2010; 15: 1359-69

78 Sepah YJ, Umer M, Ahmad T, Nasim F, Chaudhry MU, Umar M. Use of tranexamic acid is a cost effective method in preventing blood loss during and after total knee replacement. J Orthop Surg Res 2011; 6: 22

79 Lin PC, Hsu CH, Chen WS, Wang JW. Does tranexamic acid save blood in minimally invasive total knee arthroplasty? Clin Orthop Relat Res 2011; 469: 1995-2002

80 Spahn DR, Moch H, Hofmann A, Isbister JP. Patient blood management: the pragmatic solution for the problems with blood transfusions. Anesthesiology 2008; 109: 951-3

81 Perel P, Roberts I. Colloids versus crystalloids for fluid resuscitation in critically ill patients. Cochrane Database Syst Rev 2011, doi:10 1002/14651858.CD000567.pub4
82 Mitra S, Khandelwal P. Are all colloids same? How to select the right colloid? Indian J Anaesth 2009; 53: 592-607

83 Wong CJ, Vandervoort MK, Vandervoort SL, et al. A clusterrandomized controlled trial of a blood conservation algorithm in patients undergoing total hip joint arthroplasty. Transfusion 2007; 47: 832-41

84 Martinez V, Monsaingeon-Lion A, Cherif K, Judet T, Chauvin M, Fletcher $D$. Transfusion strategy for primary knee and hip arthroplasty: impact of an algorithm to lower transfusion rates and hospital costs. Br J Anaesth 2007; 99: 794-800

85 Australian Red Cross. Minimising the need for allogeneic transfusion. 2010. Available from http://www.transfusion.com.au/ transfusion_practice/overview_transfusion_practice/minimise transfusion (accessed 4 October 2011)

86 American Society of Anesthesiologists Task Force on Perioperative Blood Transfusion and Adjuvant Therapies. Practice guidelines for perioperative blood transfusion and adjuvant therapies: an updated report by the American Society of Anesthesiologists Task Force on Perioperative Blood Transfusion and Adjuvant Therapies. Anesthesiology 2006; 105: 198-208

87 Gouëzec H, Jego P, Bétrémieux P, Nimubona S, Grulois I. Indications for use of labile blood products and the physiology of blood transfusions in medicine. The French Agency for the Health Safety of Health Products. Transfus Clin Biol 2005; 12: 169-76

88 Colomina MJ, de Miguel M, Pelavski A, Castella D. Appropriateness of red blood cell use in orthopaedic surgery and traumatology: analysis of transfusion practice. Eur J Orthop Surg Traumatol 2012; 22: 129-35

89 Basora M, Colomina MJ, Moral V, et al. Descriptive study of perioperative transfusion practices in Spanish hospitals. Transfus Altern Transfus Med 2007; 10: 9-16

90 Slappendel R, Weber EW, Benraad B, Dirksen R, Bugter ML. Does ibuprofen increase perioperative blood loss during hip arthroplasty? Eur J Anaesthesiol 2002; 19: 829-31

91 Slappendel R, Dirksen R, Weber EW, van der Schaaf DB. An algorithm to reduce allogenic red blood cell transfusions for major orthopedic surgery. Acta Orthop Scand 2003; 74: 569-75

92 European Medicines Agency concludes action on COX-2 inhibitors. European Medicines Agency, 2011. Available from http:// www.ema.europa.eu/docs/en GB/document library/Press release/ 2010/01/WC500059088pdf (accessed 4 October 2011)

93 Grosser T, Fries S, FitzGerald GA. Biological basis for the cardiovascular consequences of COX-2 inhibition: therapeutic challenges and opportunities. J Clin Invest 2006; 116: 4-15

94 Inspectie voor de Gezondheidszorg. Inspectie voor de Gezondheidszorg. 2011. Available from http://www.igz.nl/ english/ (accessed 4 October 2011)

95 Horstmann WG, Ettema HB, Verheyen CC. Dutch orthopedic blood management surveys 2002 and 2007: an increasing use of bloodsaving measures. Arch Orthop Trauma Surg 2010; 130: 55-9

96 Sanquin. Sanquin blood supply website. 2011. Available from http:// www.sanquin.nl/sanquin-eng/sqn home eng.nsf (accessed 4 October 2011)

97 Preoperative Tests: The Use of Routine Preoperative Tests for Elective Surgery. Evidence, Methods \& Guidance. NHS National Institute for Clinical Excellence, 2011. Available from http://www nice org uk/nicemedia/live/10920/29094/29094 pdf (accessed 4 October 2011)

98 Boralessa H, Goldhill DR, Tucker K, Mortimer AJ, Grant-Casey J. National comparative audit of blood use in elective primary unilateral total hip replacement surgery in the UK. Ann $R$ Coll Surg Engl 2009; 91: 599-605 